\title{
Ochrana vlastních občanů v zahraničí: mezinárodněprávní souvislosti navrhované novelizace Ústavy ČR
}

\author{
Protection of Nationals Abroad: International Legal \\ Aspects of Proposed Constitutional Amendment
}

\author{
Ondřej Svaček*
}

\begin{abstract}
Abstrakt
Dne 23. 7. 2019 predložila skupina 67 poslanců návrh ústavního zákona, jehož cílem je zmèna čl. 43 Ústavy Ceské republiky spočivajici v posíleni pravomocí vlády prí rozhodováni o vysláni ozbrojených sil ČR mimo územi ČR a o pobytu ozbrojených sil jiných státu na územi Čr a o preletu nebo prijezdu ozbrojených sil jinyich státü pres územi ČR. Novelizace mj. reaguje na skutecnost, že ,podle dosavadni úpravy by naprúklad bylo mimorádnè obtí̌né véasné vysláni ozbrojených sil ČR za účelem záchrany životů občanü

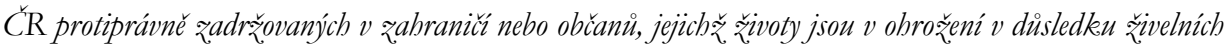
katastrof. "Vz̧hledem k tomu, že je návrh predkládán poslanci naprúc politickým spektrem (věetně predsedü A. Babiše, J. Hamáckea, P. Fialy, M. Výbornébo a V. Rakušana), lze očekávat jeho prïjetí. Clánek se zabývá mezinárodnèprávními souvislostmi navrhované novelizace Ústavy, keteré jsou v návrhu značně zjednodušeny a zodpovidá tak na otázkeu, zda současné mezuinárodni právo umožňuje použiti ozbrojené sily na územi jiného státu za účelem ochrany vlastnich občanů. Odpovéd’ na tuto otázku má prítom zásadní význam, nebot'-jak je dobř známo - ČR, a tedy i vláda, dodržuje závazky vyplývajici z mezinárodního práva, pričemž téchto závazkù se nemũze zprostit, a to ani odkazem na vlastni ústavni predpisy (srov. cl. 26 Videňské úmluvy o smluvním právu či čl. 3 Návrbu článkè o odpovédnosti státu za mezinárodnè protiprávni chování).
\end{abstract}

Klíčová slova

Ǔ̌iti sily; ochrana občanů, mezinárodníprávo.

\section{Abstract}

On 23 June, 2019, a group of 67 deputies submitted a proposal of constitutional act amending Art 43 of the Constitution of the Caech Republic. The aim of this proposal is to enhance powers of the Government in deciding on the sending of the Czech armed forces outside the territory of the Caech Republic, the stationing of the armed forces of other states within the territory of the Czech Republic, and their overflight over the territory of the republic. The amendment reacts on the fact that "according to the present regulation it would be extremely difficult to send own armed forces abroad with the aim of protection of nationals

JUDr. Ondřej Svaček, Ph.D., LL.M., Katedra mezinárodního a evropského práva, Právnická fakulta, Masarykova univerzita, Brno; Katedra mezinárodního a evropského práva, Právnická fakulta, Univerzita Palackého, Olomouc; člen centra CIHOL / Department of International and European Law, Faculty of Law, Masaryk University, Brno, Czech Republic; Department of International and European Law, Faculty of Law, Palacký University, Olomouc, Czech Republic; CIHOL center member/ E-mail: ondrej. svacek@upol.cz / ORCID: 0000-0001-5024-0529 
abroad who are unlawfully captured here or whose lives are threatened due to an ongoing natural disaster." Given the fact that the proposal was submitted by deputies across a political spectrum, it is possible to anticipate its adoption. This article is therefore focusing on international legal aspects of the amendment since they are analyzed only in a simplified form in the explanatory report. The aim of this contribution is to explain whether current international law permits the use of force abroad with the purpose of protection of nationals. The answer to this question has its obvious significance, while - as it is well known - the Czech Republic, and therefore the Government, is bound to observe its obligations arising out of international law and at the same time, in the light of Art 26 of the Vienna Convention on the Law of Treaties and Art 3 of the Draft Articles on Responsibility of States for Internationally Wrongful Acts, cannot relieve itself of these obligations by mere reference to its own constitutional regulation.

\section{Keywords}

Use of Force; Protection of Nationals; International Law.

\section{Úvod $^{1}$}

Dne 23. 7. 2019 předložila skupina 67 poslanců návrh ústavního zákona, jehož cílem je změna čl. 43 Ústavy České republiky (dále jen Ústava) spočívající v posílení pravomocí vlády při rozhodování o vyslání ozbrojených sil ČR mimo území ČR, pobytu ozbrojených sil jiných států na území ČR a o přeletu nebo průjezdu ozbrojených sil jiných států přes území ČR. Novelizace mj. reaguje na skutečnost, že ,podle dosavadní úpravy by napríklad bylo mimorádně obtižné včasné vysláni ozbrojených sil ČR za účlem záchrany životů občanu ČR protiprávně zadržovaných v zabranič nebo občanü, jejichž životy jsou v obroženi $v$ dìsledku ̌̌ivelních katastrof. "2 Vzhledem k tomu, že je návrh předkládán poslanci napříc politickým spektrem (včetně předsedů A. Babiše, J. Hamáčka, P. Fialy, M. Výborného a V. Rakušana), lze očekávat jeho přijetí. Článek se zabývá mezinárodněprávními souvislostmi navrhované novelizace Ústavy, které jsou v návrhu značně zjednodušeny a zodpovídá tak na otázku, zda současné mezinárodní právo umožňuje použití ozbrojené síly na území jiného státu za účelem ochrany vlastních občanů. Odpověd' na tuto otázku má přitom zásadní význam, nebot' - jak je dobře známo - ČR, a tedy i vláda, dodržuje závazky vyplývající z mezinárodního práva, přičemž těchto závazků se nemůže zprostit, a to ani odkazem na vlastní ústavní předpisy [srov. čl. 26 Vídeňské úmluvy o smluvním právu (dále jen VÚSP) či čl. 3 Návrhu článků o odpovědnosti státu za mezinárodně protiprávní chování (dále jen Návrh článků)].

\section{Východiska návrhu a dosavadní průběh legislativního procesu}

Návrh navazuje na současnou úpravu obsaženou v čl. 43 odst. 4 Ústavy a potvrzuje pravomoc vlády rozhodovat o vyslání ozbrojených sil ČR mimo území ČR a o pobytu

1 Předkládaný text je výstupem z projektu GAČR reg. č. 18-25279S Užití síly v mez̧inárodním právu s dưraz̨em na perspektivu zemi Visegrádské skupiny.

2 Sněmovní tisk 557, důvodová zpráva, s. 3. 
ozbrojených sil jiných států na území ČR, a to nejdéle na dobu 60 dnů. Oproti stávající úpravě však novelizace opouští kazuistický přístup, dle kterého je pravomoc vlády v otázkách vyslání a pobytu ozbrojených sil omezena na situace plnění závazků z mezinárodních smluv o společné obraně proti napadení, účasti na mírových operacích podle rozhodnutí mezinárodní organizace, jîž je ČR členem, a to se souhlasem prujímajícího státu, nebo účasti na záchranných pracích při živelních pohromách, průmyslových nebo ekologických haváriích. Dle důvodové zprávy je naznačený kazuistický přístup nadále nevyhovující, nebot' „neumožñuje rychlé vysláni ozbrojených sil ČR za účelem záchrany občanù CR $v$ zabranič a provádèni opatreni proti nelegálni migraci v rámci spolupráce s ozbrojenými silami jiných státü", přičemž „rychlé vysláni ozbrojených sil ČR mưže být žádoucí $i$ v jiných prǐpadech, jako napr. mnohonárodni operace ke stabilizaci z̧hroucených států. "3

Rovnou budiž řečeno, že takto pojaté odůvodnění nevyznívá z větší části zcela přesvědčivě. Zejména stabilizace tzv. zhroucených států jistě nebude dosahováno operativními prostředky umožňujícími vojenské nasazení toliko na dobu do 60 dní. Pochybnosti lze mít rovněž o účelu v podobě provádění opatření proti nelegální migraci na území jiných států, a to již z toho důvodu, že se jedná o zprofanované, zpolitizované a českými politiky zneužívané [a s ohledem na nedostatek veřejně prezentovaného objektivního zhodnocení širších (mezinárodně)právních souvislostí též nezvládnuté] téma, které má dle názoru autora předkládaného článku přispět spíše jen $\mathrm{k}$ navození pocitu zvýšené potřeby prijetí předkládané novely. ${ }^{4} \mathrm{Z}$ naznačeného cíle a účelu navrhované novelizace Ústavy lze proto považovat za relevantní především ochranu vlastních občanů v zahraničí, které proto bude věnována pozornost v následujícím textu. Nejdříve je však vhodné alespoň stručně zmínit stanoviska prezentovaná v průběhu připomínkového řízení.

Z relevantních připomínek lze v prvé řadě odkázat na stanovisko Ministerstva zahraničních věcí (dále též $\mathrm{MZV}$ ), jež zdůraznilo, že vláda je př̀i svém rozhodování vázána čl. 1 odst. 2, čl. 10 a čl. 10a Ústavy, tedy, že je vázána mezinárodním právem. MZV uvedlo, že „vláda bude muset vždy rádně qdìvodnit, že dané vysláni neni v rozporu s mezinárodněprávními závazky Čr a za rozhodnutí o vysláni si ponese odpovédnost nikoliv jen politickou, ale i právni "' príičemž připomnělo, že je ČR vázána Ř́mským statutem Mezinárodního trestního soudu,

3 Ibid., s. 7.

4 Postačí uvést snad jen odkaz na rozsudek Evropského soudu pro lidská práva (ESLP) z 3. 10. 2017, ve věci N. D. a N. T. proti Španélsku, v němž bylo zdůrazněno, že hraniční kontroly a bromadné navracení do země, z níž migranti přicházejí, je v rozporu s Úmluvou o ochraně lidských práva a základních svobod (EÚLP). Ve věci Sharifi a ostatní proti Itálii a Řecku (rozsudek ze dne 21. 10. 2014) ESLP zdůraznil právo na př́stup $\mathrm{k}$ azylovému řízení. Z pohledu mezinárodního práva je významné, že účastí na prrípadném porušování mezinárodněprávních závazků, jehož se dopouštějí jiné státy, by ex lege nastupovala spoluodpovědnost ČR za pomoc nebo podporu při mezinárodně protiprávním chování (srov. čl. 16 Návrhu článků - FAIX, M. a kol. Rukovét ke studiu mezinárodního práva I: Dokumenty. Praha: Leges, 2015, s. 299).

5 Stanovisko Ministerstva zahraničních věcí, Př́loha k č. j. 130858/2019-OPL, s. 2. 
do jehož věcné působnosti nově spadá rovněž zločin agrese. ${ }^{6}$ Ministerstvo současně zdůraznilo svůj dlouhodobě zastávaný názor, že vyslání ozbrojených sil za účelem záchrany životů občanů ČR protiprávně zadržovaných v zahraničí nespadá pod čl. 43 Ústavy.

Ministerstvo dopravy označilo návrh za diskutabilní, a to zejména ve vztahu k pobytu ozbrojených sil cizího státu na území ČR. Současná právní úprava, obsahující taxativní omezení situací, v nichž je možno rozhodnout o vyslání či pobytu ozbrojených sil, má dle názoru ministerstva dopravy své opodstatnění i v současné době, zejména s ohledem na historickou zkušenost Československa. Ministerstvo připomnělo, že uvedený návrh byl již jednou předložen a projednáván v letech 2016-2017 jako sněmovní tisk č. 956, přičemž nedošlo k jeho schválení. ${ }^{7}$

Ministerstvo vnitra se s navrženou úpravou rozhodovací pravomoci vlády, pokud jde o vysílání ozbrojených sil ČR mimo její území, věcně ztotožnilo, nicméně zdůraznilo, že by „v diovodové zprávě uvitalo adekvátni rozbor souvisejicího mezinárodníbo práva, jelikož vyslání českých ozbrojených sil na územi jiného státu bezjeho soublasu vyvolává otázky, zda by tento krok. nebyl rozporný s mezinárodním právem. "8

Stanoviska ostatních ministerstev nejsou s ohledem na text předkládaného článku, zaměřujícího se na rozbor mezinárodněprávního rámce vojenské ochrany občanů v zahraničí, důležitá. Překvapivé je snad pouze to, že se k návrhu obsáhleji nevyjádřil rezort obrany, coby gestor problematiky, jenž se omezil toliko na konstatování souhlasu.

Připomínky ministerstev lze rozdělit do dvou skupin. Ve vztahu k internímu aspektu návrhu, tj. pobytu cizích ozbrojených sil na území ČR, je zpochybňována (mj. v souvislosti s debatami o předchozím neúspěšném návrhu, jenž byl projednáván v letech 20162017) samotná nutnost změny stávající ústavněprávní úpravy a rozšíření existujících pravomocí vlády. Ve vztahu k externímu aspektu, tj. vyslání ozbrojených sil ČR do zahraničí, je poukazováno na chybějící rozbor, jenž by osvětlil, zda by byl postup vlády v konkrétním prrípadě v souladu s mezinárodněprávními závazky ČR. Skromným cílem předkládaného článku je právě doplnění mezinárodněprávních souvislostí předmětného návrhu; internímu aspektu není věnována pozornost.

Dne 26. 8. 2019 vyslovila vláda s předloženým návrhem souhlas. V době dokončení textu (konec záŕi 2019) byl legislativní proces ve fázi prvního čtení.

6 Srov. SVAČEK, Ondřej. Mezinárodni trestni soud (2005-2017). Praha: C. H. Beck, 2017, s. 48, s. 246.

7 Stanovisko Ministerstva dopravy, Př́loha k č. j. 147/2019-510-LV/3, s. 2. Obdobnou připomínku vzneslo též Ministerstvo zemědělství, jež zdůraznilo, že v předkládaném návrhu není vysvětleno, proč by omezující podmínky neměly být aplikovány v případě pobytu cizích vojsk na území ČR - srov. Stanovisko Ministerstva zemědělství, Př́loha k č. j. 40854/2019-MZE-11192, s. 1. Ve stejném duchu se vyslovilo též Ministerstvo zdravotnictví a Ministerstvo financí. Dle Ministerstva zdravotnictví z návrhu nevyplývá, proč je nezbytné rozšíření pravomoci vlády i ve vztahu k pobytu cizích vojsk na území ČR - srov. Stanovisko Ministerstva zdravotnictví, č. j.: 34220/2019/LEG, s. 1. Dále Stanovisko Ministerstva financí, č. j. MF-19476/2019/7101-4, s. 1.

8 Stanovisko Ministerstva vnitra, č. j. MV-106234-5/LG-2019, s. 1. 


\section{Mezinárodněprávní souvislosti}

Samotný návrh je co do odkazu na mezinárodněprávní úpravu dosti skoupý. Poměrně suverénně konstatuje, že není v rozporu s mezinárodními smlouvami, jimiž je ČR vázána. Uvádí, že „na oblast navrhované právni úpravy se vątabuji mezinárodni smlonvy v oblasti kolektivní obrany, jimiž jsou Charta Spojených národů (publikovaná pod c.. 30/1947 Sb.) a Severoatlantická smlowva (publikovaná pod č. 66/1999 Sb.). Navrbovaná úprava umožní, aby ČR efeketivnèji plnila své závazky upplyvajicí z tèchto mezinárodnich smluv. "9 Lze se tedy ptát, zda z Charty OSN (dále jen Charta), potažmo z obyčejového mezinárodního práva, o kterém není přes jeho zásadní význam v oblasti zákazu užití síly v návrhu jediná zmínka, vyplývá aávazẹe chránit vlastní občany v zahraničí? Nutno dodat, že výraz závazek evokuje povinnost chovat se určitým způsobem. V prrípadě užití síly na území jiného státu by však bylo prríhodnější zabývat se tím, zda je stát vůbec oprávněn takto postupovat. Návrh je v prvé řadě nutné zasadit do kontextu relevantní mezinárodněprávní úpravy.

\subsection{Co vlastně stanoví Charta OSN a obyčejové mezinárodní právo?}

Je obecně známo, že základní normou současného mezinárodního práva je kogentní (a tedy obyčejové) stanovení zákazu užití síly. Charta, jíž se návrh dovolává, zákaz užití síly koncipuje jako zásadu, na níž je vystavěno fungování OSN (čl. 2 odst. 4). Současně však z tohoto zákazu stanoví dvě nesporné výjimky, o jejichž právní povaze nelze v obecné rovině pochybovat: sebeobranu (čl. 51) a kolektivní donucovací akci (čl. 42) pod záštitou Rady bezpečnosti OSN (dále jen RB). ${ }^{10}$ Charta je současně stěžejním dokumentem, $\mathrm{z}$ něhož je nutné vycházet i v př́padech, kdy by $\mathrm{k}$ užití síly došlo ze strany NATO, jakožto tzv. oblastní organizace či dohody. ${ }^{11}$ Lze rríci, že pokud by došlo k užití síly (a nasazení ozbrojených sil ČR v zahraničî) v rámci sebeobrany (reagující na ozbrojený útok proti území ČR, resp. při kolektivní sebeobraně reagující na útok vǔči spojenci, který by o to ČR požádal) ${ }^{12}$ či kolektivní donucovací akce OSN, byt' realizované např. prostřednictvím NATO, jednalo by se o zásah souladný s mezinárodním právem,

9 Důvodová zpráva, s. 14.

10 Jedním dechem je však nutno zmínit, že kontroverze se nevyhýbají ani obsahu a rozsahu těchto dvou ustálených výjimek (např. ve smyslu př́pustnosti anticipatorní a preventivní sebeobrany, sebeobrany proti ozbrojenému útoku nestátního aktéra nebo př́pustnosti následného schválení užití síly ze strany RB OSN). Vedle ustálených výjimek lze rovněž odkázat na tzv. šedou zónu v oblasti zákazu užití síly, do níž patř́ humanitární intervence, intervence na pozvání (konkrétně v situacích občanských válek, kdy $\mathrm{v}$ daném státě existuje více center, která uplatňují veřejnou moc a aspirují na zastupování tohoto státu navenek) a užití síly v kontextu národního sebeurčení.

11 Charta v čl. 53 odst. 1 stanoví, že tam, kde je to vhodné, použije RB takových oblastních dohod nebo orgánů pro donucovací akci pod svým vedením. Avšak žádná donucovací akce nebude podniknuta podle oblastních dohod nebo oblastními orgány bez zmocnění RB.

$12 \mathrm{~K}$ podmínkám kolektivní sebeobrany srov. DAVID, Vladislav a kol. Mezinárodní právo verejné s kazuistikou. 2. vyd. Praha: Leges, 2011, s. 356. 
jenž by tím pádem nevyvolával kontroverze ani z pohledu vnitrostátních procedur. Obdobně by tomu bylo v prrípadě, že by k nasazení ozbrojených sil ČR v zahraničí došlo se souhlasem přijímajícího státu. Záměr předkládaného návrhu novelizace Ústavy však zřejmě směřuje $\mathrm{k}$ situacím odlišným, tj. $\mathrm{k}$ situacím, u nichž by nebyl dán souhlas teritoriálního státu, ani mandát RB OSN či předchozí ozbrojený útok na území ČR, který by zakládal právo na sebeobranu, tedy k situacím, jež lze považovat za jednostranné užití síly za účelem ochrany vlastních občanů v zahraničí. Jako vzorový a učebnicový př́íklad lze použít známý incident v Entebbe v roce $1976 .{ }^{13}$

\subsection{Jednostranné užití síly za účelem ochrany občanů v zahraničí}

Krátce po zveřejnění komentovaného návrhu novelizace Ústavy se k němu vyjádřil J. Kudrna, který v reakci na slova bývalého náčelníka generálního štábu, J. Šedivého, o nutnosti dodržovat mezinárodní právo uvedl, že mezinárodní právo intervenci ve prospěch unesených občanů připouští, nebot' ,je povinností každého normálního státu pomáhat svým občanuim v nouzi."14 Kudrna tudíž nedohledává pouhé oprávnění, ale rovnou hovoří o existenci závazku. Bližší pohled nicméně odhaluje, že právní hodnocení není ani zdaleka tak jednoznačné. ${ }^{15}$

Nauka se totiž shoduje snad jen v tom, že užití síly za účelem ochrany vlastních občanů v zahraničí bylo povolené, nicméně jen do roku $1945 .^{16}$ Jak např. uvádí ve svém referenčním díle L. Oppenheim, právo ochrany vlastních občanů, jimž bylo v zahraničí ublíženo nebo jejichž majetek byl poškozen, mohlo být realizováno různými způsoby: „Domovský stát mobl požadovat potrestáni pachateli, uplatnit retorzni č represivni opatrení, prístoupit k intervenci nebo v prípadě nutnosti též vstoupit do války. “17 Charta však představuje zásadní milník mezinárodněprávní regulace užití síly, což znamená (jak bude uvedeno dále), že dovolávat se v současné době čehokoliv, co jí předchází, vede k více než sporným výsledkům.

13 KRESS, Claus a Benjamin NUSSBERGER. The Entebbe Raid - 1976. In: RUYS, Tom et al. (eds.) The Use of Force in International Law: A Case-Based Approach. Oxford: OUP, 2018, s. 220-233.

14 GAZDÍK, Jan. Máme síly rychlé reakce, ale rychle je vyslat neumíme. Poslanci sepsali novelu ústavy. Aktuálně.cz [online]. Zveřejněno dne 29. 7.2019 [cit. 7. 9. 2019].

15 Dle T. Ruyse se jedná o jedno z nejostřeji diskutovaných témat v oblasti ius ad bellum. Srov. RUYS, Tom. ,Armed Attack' and Article 51 of the UN Charter: Evolutions in Customary Law and Practice. Cambridge: CUP, 2010, s. 214; Část nauky poukazuje na přetrvávající nejistotu stran mezinárodněprávní regulace, což vysvětluje rozporem mezi faktem (chováním států) a právem. Srov. FORTEAU, Mathias. Rescuing Nationals Abroad. In: WELLER, Marc (ed.). The Oxford Handbook of the Use of Force in International Law. Oxford: OUP, 2015, s. 947.

16 BROWNLIE, Ian. International Law and the Use of Force by States. Oxford: Clarendon Press, 1968, s. 289; Pro shrnutí relevantní literatury srov. GÜVEN, Onur a Olivier RIBBELINK. Protection of Nationals Abroad: A Return to Old Practice? In: PAULUSSEN, Christophe et al. (eds.) Fundamental Rights in International and European Law. Hague: T. M. C. Asser Press, 2016, s. 48-51.

17 OPPENHEIM, Lassa. International Law: A Treatise. London: Longman, Green, and Co., 1905, s. 375. 
Akce učiněné za účelem ochrany vlastních občanů v zahraničí mohou proběhnout v kontextu různých skutkových okolností, což má ovšem vliv na jejich následné právní hodnocení. Zaprvé je možné rozlišit tzv. nevojenské (nebojové) evakuační operace, které se odehrávají na pozadí situací vnitřních nepokojů či ozbrojených konfliktů, u nichž nejsou vlastní občané v zahraničí bezprostředně či prrímo ohroženi, přesto je domovským státem zajištěn jejich návrat do vlasti, resp. převoz do bezpečí. ${ }^{18}$ Vzhledem $\mathrm{k}$ tomu, že u těchto operací nedochází $\mathrm{k}$ použití ozbrojené síly, lze říci, že neodporují shora uvedenému zákazu užití síly vyplývajícímu z čl. 2 odst. 4 Charty a obyčejového mezinárodního práva. Současně však nelze bez dalšího říci, že by taková akce byla v souladu s mezinárodním právem - pokud by k ní totiž došlo bez souhlasu přijímajícího státu, což je presumováno, jednalo by se striktně vzato o rovněž zakázanou formu vměšování se do vnitřních záležitostí jiného státu, resp. o zakázaný výkon pravomoci na území jiného státu. ${ }^{19} \mathrm{~V}$ tomto případě by však bylo možné argumentovat okolnostmi vylučujícími protiprávnost, konkrétně tísní, případně též krajní nouzí. ${ }^{20}$ Uvedený typ záchranné akce je nejméně kontroverzní, lze vysledovat silný názorový proud, který v takových př́padech hovoří o výkonu práva domovského státu. ${ }^{21}$

Druhý scénár již zahrnuje aspekt užití síly. Jedná se o situace, v rámci kterých se evakuační operace popsané v předchozím odstavci setkají s vojenským odporem, at’ už ze strany státu nebo nestátního aktéra. Konečně třetí scénář je silový od samého svého počátku, typicky se jedná o situace, kdy jsou vlastní občané již bezprostředně ohroženi (např̀. jsou zajati coby rukojmî). Jak vyplyne z následujícího textu, právní hodnocení druhého

18 Jako př́klad lze uvést evakuační akce Francie ve Středoafrické republice v letech 1996 a 2003, v Gabonu v roce 2007 a v Čadu v roce 2008. Dále akce Belgie v Kongu v letech 1960 a 1964, akce Spojených států v Libérii v roce 1990, nebo akce Německa v Albánii v roce 1997 a v Libyi (tzv. operace Pegasus) v roce 2011.

19 Deklarace zásad mezinárodního práva týkajících se přátelských vztahů a spolupráce mezi státy, zásada 3 (srov. FAIX, M. a kol.: op. cit., s. 28). Jak plyne z rozsudku Stálého dvora mezinárodní spravedlnosti (SDMS) v kauze Lotus, první a základní omezení, které státům plyne z mezinárodního práva, je, že státy nemohou vykonávat donucovací pravomoc na území jiných států, pakliže není stanoveno jinak. Srov. SDMS, SS. Lotus (Francie proti Turecku), 1927, s. 18.

20 Uplatnění těchto institutů přitom není vyloučeno, nebot’ obě uvedená pravidla nemají - na rozdíl od zákazu užití síly - kogentní povahu (srov. čl. 24-26 Návrhu článků).

21 FORTEAU, op. cit., s. 960. V argumentaci lze navíc zajít ještě dále. Lze se totiž ptát, zda je v souladu s mezinárodním právem postup, $\mathrm{v}$ rámci kterého dochází $\mathrm{k}$ evakuaci pouze vlastních občanů za současného odmítnutí evakuace občanů třetích států, zejména občanů státu teritoriálního. Mezinárodní soudní dvůr (MSD) totiž ve sporu Nikaragua proti Spojeným státüm uvedl, že „,humanitární pomoc musí být predevšim poskytována bez rozlišování. "Srov. MSD. Vojenské a polovojenské aktivity v Nikaraguy a proti ní (Nikaragua proti Spojeným státưm). 1986, odst. 243. 
a třetího scénáře je značně sporné, ${ }^{22}$ zůstává nevyřešené, ${ }^{23}$ což se odráží rovněž v široké paletě doktrínou prezentovaných názorů. ${ }^{24}$

$\mathrm{V}$ prvé řadě se objevují názory, dle kterých v př́padě ochrany vlastních občanů nelze vůbec hovořit o užití síly, resp. o jednání, jež by spadalo do rámce zákazu užití síly, nebot’ intervenující stát nejedná s úmyslem narušit územní celistvost či politickou nezávislost teritoriálního státu ve smyslu předvídaném v čl. 2 odst. 4 Charty. ${ }^{25}$ Tento přístup vychází z předpokladu, že užití síly na území jiného státu může sledovat i jiné, v zásadě bohulibé cíle (typicky humanitární intervence), z čehož jsou dovozovány závěry o legalitě takových akcí.

$\mathrm{S}$ odkazem na podpůrný prostředek výkladu mezinárodních smluv v podobě tzv. přípravných prací, předvídaný v čl. 32 VÚSP a použitelný coby kodifikace obyčejového mezinárodního práva, lze formulovat závěr, že úmyslem tvůrců Charty bylo stanovení absolutního a všezahrnujícího zákazu užití síly v mezinárodních vztazích, o čemž svědčí slovní spojení čl. 2 odst. 4 Charty, jenž hovoří o povinnosti zdržet se užití síly jakýmkoliv jiným zpưsobem. ${ }^{26}$ Relevantní je rovněž závěr MSD v případu Korfskébo prilivu, jenž odmítl argumentaci Velké Británie, která odůvodňovala své akce (odstraňování min) $\mathrm{v}$ teritoriálních vodách Albánie snahou zajistit důkazy pro řízení před tímto mezinárodním soudním orgánem, přičemž se explicitně dovolávala čl. 2 odst. 4 Charty a uváděla, že její jednání neodporuje politické nezávislosti, územní celistvosti či cílům OSN. ${ }^{27}$ Dle převládajícího názoru tedy platí, že pokud operace na území jiného státu zahrnuje užitî síly (pochopitelně za konstantně uplatňovaného předpokladu, že teritoriální stát nedal k takovému zásahu předchozí souhlas), jednoznačně odporuje čl. 2 odst. 4 Charty a souběžně existujícímu mezinárodnímu obyčeji. ${ }^{28}$ Stručně a výstižně řečeno Cimrmanem: tudy cesta nevede. Lze snad jen doplnit, že relevanci shora nastíněného bohulibého cíle snad nejlépe vystihl O. Schachter, dle kterého ,je myšlenka, že války vedené ze spravedlivých divvodi jako demokracie a lidská práva nepredstavuji porušeni územni celistvosti či politické nezávislosti vyžaduje orwellovský prístup k. tèmto výrazuim. "29

22 BÍLKOVÁ, Veronika. Mezinárodněprávní aspekty vývoje na Krymu. Working Papers České společnosti pro mezinárodní právo, 2014, roč. 1, č. 1, s. 11.

23 FORTEAU, op. cit., s. 961.

24 RUYS, op. cit., s. 214.

25 Charta OSN v čl. 2 odst. 4 stanoví, že všichni členové se vystříhají ve svých mezinárodních stycích hrozby násilím nebo použití násilí at' proti územní celistvosti nebo politické nezávislosti kteréhokoli státu, at’ jakýmkoli jiným způsobem neslučitelným s cíli Spojených národů. Z dnes již klasické literatury srov. RONZITTI, Natalino. Rescuing Nationals Abroad Through Military Coercion and Intervention on Grounds of Humanity. Dordrecht: Martinus Nijhoff, 1985, s. 1.

26 UNIO. Documents of the United Nations Conference on International Organization, San Francisco, 1945, roč. 6, s. 335 .

27 MSD. Korfský průliv (Velká Británie proti Albánii). 1949, s. 35.

28 Obdobně International Law Association, Final Report on Aggression and the Use of Force, 2018, s. 18.

29 SCHACHTER, Oskar. The Legality of Pro-Democratic Invasion. American Journal of International Law, 1984 , roč. 78 , č. 3 , s. 649. 
Má-li tedy být vojenská operace za účelem ochrany vlastních občanů považována za souladnou s mezinárodním právem, je nutno dohledat právně relevantní výjimku, jež by porušení všeobecně stanoveného zákazu užití síly ospravedlňovala. Spektrum teorií a praxí předkládaných výjimek je poměrně široké, zahrnuje sebeobranu, krajní nouzi či tíseň, externě systematický argument v podobě ochrany lidských práv (humanitární intervence sui generis) a v neposlední radě též ochranu vlastních občanů pojímanou jako svébytnou výjimku per se.

Nejčastěji využívaným institutem sloužícím k ospravedlnění užití síly za účelem ochrany vlastních občanů v zahraničí je sebeobrana. Uplatňování této výjimky však rovněž není jednotné. Dle jednoho z doktrinárních př́stupů, navazujícího na dílo H. Waldocka, ${ }^{30}$ je možné vycházet z obyčejové regulace sebeobrany ustálené před rokem 1945, jež by se uplatňovala nezávisle na smluvní úpravě zakotvené v čl. 51 Charty. ${ }^{31}$ Řečeno jinak, jestliže platí - jak bylo uvedeno výše - že v období předcházejícím přijetí Charty byl tento typ intervence př́pustný, nebot' se jednalo o legální výkon práva na sebeobranu, lze se dle názoru části nauky tohoto přirozeného (obyčejového) práva ve stejném rozsahu dovolávat rovněž po roce 1945.

Základní otázkou ovšem zůstává, zda regulace použitelná před rokem 1945 „přežila“ kritický moment přijetí Charty a následující období. Předně lze uvést, že otázka vzájemného vztahu Charty a preexistujícího obyčeje je nepřekvapivě kontroverzní. ${ }^{32}$ Poměrem obou pramenů mezinárodního práva v oblasti zákazu užití síly se zabýval MSD v rozsudku ve věci Nikaragua proti Spojeným státuim z roku 1986, jehož nosné a nadále platné závěry lze shrnout následovně:

1. MSD nepřisvědčil názoru Spojených států, že pravidla obyčejového mezinárodního práva týkající se užití síly jsou totožná s příslušnými ustanoveními Charty, nebot' shledal, že v mnoha aspektech se oba prameny zcela nepřekrývají a daná hmotněprávní pravidla nejsou co do jejich obsahu totožná, ${ }^{33}$ což lze nejlépe ukázat právě na institutu sebeobrany (ve smyslu obyčejovým právem stanovených podmínek přiměřenosti a nezbytnosti, resp. Chartou dané informační povinnosti vưči RB OSN); ${ }^{34}$

30 WALDOCK, Humprey. The regulation of the use of force by individuals states in international law. Collected Courses of the Hague Academy of International Law, Leiden, Boston: BRILL Nijhoff, 1951, roč. 81.

31 Charta v čl. 51 stanoví, že dojde-li k ozbrojenému útoku proti některému členu Spojených národů, nic v Chartě není na překážku príroz̧enému právu na individuální nebo kolektivní sebeobranu. Právě ustanovení, že nic v Chartě není na překážku přirozenému právu na sebeobranu, použivá část nauky jako argument, že obyčejové mezinárodní právo sebeobrany, poskytující mandát nejen k ochraně vlastních občanů, ale rovněž k tzv. anticipatorní sebeobraně, je nadále aplikovatelné.

32 Literatura dokonce hovoří o schizmatu mezi tzv. restriktivní školou a expanzivní školou - srov. RUYS, op. cit., s. 9.

33 Rozsudek MSD ve věci Nikaragua proti Spojeným státuim, odst. 181.

34 Rozsudek MSD ve věci Nikaragua proti Spojeným státuim, odst. 176. 
2. Uvedl, že i kdyby byla smluvní a obyčejová pravidla v oblasti užití síly zcela totožná, bylo by nutné zachovávat jejich svébytnou existenci (v daném případě totiž Spojené státy výhradou vyloučily použití smluvního mezinárodního práva, tj. Charty); ${ }^{35}$

3. Zdůraznil, že Charta sama na preexistující obyčejové právo odkazuje, nebot' použití výrazu přirozené právo na sebeobranu v čl. 51 Charty nemůže být vykládáno jinak, než ve smyslu obyčejového mezinárodního práva; ${ }^{36}$

4. Konstatoval, že Charta vyjádřila zásady již tehdy tvořící součást obyčejového mezinárodního práva, kteréžto se v následujících čtyřech desetiletích vyvijelo pod vlivem Charty; ${ }^{37}$

5. Uzavřel, že obyčejová i smluvní pravidla sledují stejný účel, tj. považují užití síly za rozporné s mezinárodním právem. Jestliže $\mathrm{v}$ obsahu těchto pravidel existujî rozdíly, nejsou takového druhu, že by rozsudek založený v daném případě toliko na obyčejovém mezinárodním právu byl nedostatečný. ${ }^{38}$

Ze závěrů MSD vyplývá, že obyčejová a smluvní (tj. obsažená v Chartě) pravidla týkající se sebeobrany nejsou totožná, existují vedle sebe, doplňují se, lze říci, že jsou komplementární. ${ }^{39}$ Podstatné je, že mezi oběma typy pramenů mezinárodního práva dle MSD neexistuje konfliktní vztah, resp. i kdyby kdy existoval, byl plynutím času překonán. Vzhledem k následné, několik desetiletí trvající souběžné koexistenci totiž došlo fakticky ke sloučení obyčejové a smluvní úpravy. Řečeno jinak, Charta OSN v současné době představuje kodifikaci obyčejového mezinárodního práva. ${ }^{40} \mathrm{Z}$ uvedeného vyplývá, že nemůže nastat situace, kdy by stát uplatňující sebeobranu jednal v souladu s obyčejovým mezinárodním právem, ale porušoval přitom Chartu, nebot' rámec právní úpravy je jednotný. Dovolávat se časů dávno minulých, tedy úpravy před rokem 1945, v systému, jemuž dominuje Charta, je tudíž bezpředmětné.

V takovém prŕpadě by však byla ozbrojená akce za účelem ochrany občanů v zahraničí v souladu s Chartou (a tedy i obyčejovým mezinárodním právem) jedině tehdy, pokud by ozbrojený útok, jakožto předpoklad realizace práva na sebeobranu, měl nejenom

35 Rozsudek MSD ve věci Nikaragua proti Spojeným státuim, odst. 179.

36 Rozsudek MSD ve věci Nikaragua proti Spojeným státům, odst. 176. MSD tudíž jednoznačně odmítl tezi, že by výraz přirozené právo (v angličtině inherent right, resp. ve francouzštině droit naturel) měl být chápán ve smyslu opaku práva pozitivního, z čehož vycházel např. H. Kelsen - srov. RUYS, op. cit., s. 66. Výraz přirozené právo je konečně naukou vykládán nikoliv jen věcně (tj. ve smyslu obsahu právní úpravy), ale rovněž ve smyslu právních účinků (tj. sebeobrana může být realizována též státy, které nejsou smluvní stranou Charty) - srov. SIMMA, Bruno et al. (eds.). The Charter of the United Nations: A Commentary. Vol. 2. 3. vyd. Oxford: OUP, 2012, s. 1403.

37 Ibid., odst. 181

38 Ibid.

39 MALENOVSKÝ, Jiří. Mezinárodni právo verejné. Obecná část a pomèr kejüým právním systémüm. 6. vyd. Praha, Plzeň: Doplněk, Aleš Čeněk, 2014, s. 173.

40 DINSTEIN, Yoram. War, Aggression and Self-Defence. 5. vyd. Cambridge: CUP, 2011, s. 100. 
rozměr teritoriální (útok směřující proti území státu), ${ }^{41}$ ale rovněž rozměr personální (útok směřující proti občanům). Z tohoto přístupu vycházel zvláštní zpravodaj Komise OSN pro mezinárodní právo J. Dugard ve své úvodní zprávě předložené k tématu diplomatické ochrany, jenž dospěl k závěru, že ,hroz̧a či uřití síly prì výkonu diplomatické ochrany mohou být ospravedlnèny jedině za predpokladu, že jsou pojímány jako sebeobrana. "42 Stejnou systematiku zvolilo rovněž Sdružení pro mezinárodní právo (ILA). ${ }^{43}$ Tato teze má určité ratio, nemůže být bez dalšího odmítnuta, nebot’ stát je amalgámem území a obyvatelstva, nicméně není přijímána jednomyslně. Např. O. Dörr uvádí, že „ozbrojená akece za účelem záchrany občanů nemưž být ospravedlňována sebeobranou, jak se často děje v praxi států, nebot' $v$ takové situaci chybi teritoriálni prvek, jenžje vyžadován pro naplnèni znakư ozbrojeného útoku. "44 Odpůrci personálního rozměru ozbrojeného útoku jsou toho názoru, že nebezpečí, byt' zcela bezprostřední a skutečné, hrozící toliko několika občanům nemůže být srovnáváno s intenzitou ozbrojeného útoku směrujícího proti území státu. ${ }^{45} \mathrm{~S}$ ohledem na přetrvávající rozkoly v doktríně - reflektující praxi států - je bohužel nutné konstatovat, že tato otázka zůstává sporná.

Obdobně je tomu ve vztahu k další a již tradiční výzvě spjaté se sebeobranou, tj. její použitelností $\mathrm{v}$ př́padě ozbrojených útoků ze strany nestátního aktéra. Je více než pravděpodobné, že pokud by v budoucnu došlo např. k únosu českých občanů v zahraničí,

41 Teorie i praxe současně akceptují, že za ozbrojený útok na stát se považuje rovněž útok na jeho lodě, letadla (včetně lodí a letadel soukromých) a zastupitelské úřady. Srov. GREENWOOD, Christopher. Self-Defence. In: LACHENMANN, Frauke a Rüdiger WOLFRUM (eds.). The Law of Armed Conflict and the Use of Force. The Max Planck Encyclopedia of Public International Law. Oxford: OUP, 2017, s. 1133-1134. Nejednoznačné je hodnocení izolovaného útoku na státní představitele (zejména diplomatické zástupce a vnitrostátní orgány pro zastupování státu navenek) v zahraničí - srov. RUYS, op. cit., s. 204.

42 A/CN.4/506, 219, odst. 55. Zvláštní zpravodaj předložil návrh čl. 2 následujícího znění: Hrozba či užití síly představují zakázané prostředky diplomatické ochrany s výjimkou případů záchrany vlastních občanů, jestliže: (a) stát vykonávající ochranu vlastních občanů neuspěl s jejím výkonem pokojnými prostředky, (b) stát škůdce je neochoten či neschopen zajistit ochranu občanů státu vykonávajícího diplomatickou ochranu, (c) občané státu vykonávajícího diplomatickou ochranu jsou vystaveni bezprostřednímu nebezpečí, (d) užití síly je prriměřené okolnostem situace, (e) užití síly je ukončeno a stát vykonávající diplomatickou ochranu stáhne ozbrojené síly neprodleně poté, co dojde k záchraně jeho občanů. Návrh článku tohoto znění nakonec nebyl přijat s odůvodněním, že diplomatická ochrana nemá cokoliv společného s užitím síly, resp. užití síly nepatří mezi přípustné prostředky výkonu diplomatické ochrany srov. Yearbook of the International Law Commission, vol. II, Part Two. 2006, s. 27-28, odst. 8; Jak uvádí Ruys, tomuto návrhu vyslovili podporu toliko dva členové Komise OSN pro mezinárodní právo, resp. jediný stát (Itálie) v rámci následné debaty v Šestém výboru Valného shromáždění OSN - srov. RUYS, op. cit., s. 237-238.

43 ILA. Final Report on Aggression and the Use of Force. 2018, s. 2.

44 DÖRR, Oliver. Use of Force, Prohibition of. In: LACHENMANN, Frauke a Rüdiger WOLFRUM (eds.). The Law of Armed Conflict and the Use of Force. The Max Planck Encyclopedia of Public International Law. Oxford: OUP, 2017, s. 1296; Pro přehled názorů srov. KRESS, NUSSBERGER, op. cit., s. 228 a RUYS op. cit., s. 215-216.

45 Dinstein na druhé straně uvádí, že pokud je na jednotlivce zaútočeno právě kvůli jejich občanství a vazbě na konkrétní stát, je to totéž, jako kdyby bylo zaútočeno na stát. Srov. DINSTEIN, op. cit., s. 258. 
původcem takového jednání by byl nejspíše nestátní aktér (typicky teroristická organizace), což zdůrazňuje rovněž důvodová zpráva. ${ }^{46}$ Může tedy být nestátní aktér původcem ozbrojeného útoku?

Text Charty na tuto otázku odpověd’ nedává, k jednoznačnému závěru nelze dospět ani po prostudování jejích př́pravných prací. Př́iznivci restriktivního pojetí tradičně odkazujî na judikaturu MSD, z níž lze dovodit, že původcem ozbrojeného útoku může být toliko stát, případně entita, jejîž jednání je státu přičitatelné. ${ }^{47}$ Tématu je v nauce nadále věnována značná pozornost, názory nejsou jednotné, nicméně ve shodě se závěrečnou zprávou ILA týkající se užití síly v mezinárodním právu lze střízlivě konstatovat, že „v praxi státu lze vysledovat rostouci uznáni, že za určitých okolností má napadený stát právo sebeobrany proti ozbrojeným útokìm nestátního aktéra, které nemohou být pričteny hostitelskému státu. "48 Jednou z těchto podmínek (okolnostî) je subsidiarita, z níž vyplývá, že k ozbrojené akci na území hostitelského státu může být přistoupeno teprve poté, co je tomuto státu dána možnost sjednat nápravu vlastními prostředky, přičemž se ukáže, že jeho postup je neefektivní, nebot' proti nestátnímu aktéru není schopen či ochoten zasáhnout.

Lze tak shrnout, že sebeobrana zakotvená v čl. 51 Charty by mohla být využita coby právní základ odůvodňující vojenskou záchrannou akci vlastních občanů v zahraničí jen za předpokladu přijetí liberálního výkladu pojmu ozbrojený útok, počítaje v to rovněž původce tohoto útoku.

Jestliže byl výše naznačen rozdíl mezi oprávněním a závazkem, přičemž předcházející text dohledával alespoň oprávnění k užití síly na území jiného státu za účelem ochrany vlastních občanů, $\mathrm{k}$ závazku, a tedy $\mathrm{k}$ povinnosti postupovat silově, má nejblíže názorový proud zdůrazňující lidskoprávní či humanitární ohledy. ${ }^{49}$ Nelze mu však přisvědčit. Předně, jen stěží je možno předpokládat, že by pozitivní lidskoprávní závazek státu pưsobit preventivně v situacích, kdy je ohrožen život jednotlivce, zahrnoval rovněž scénár̆, jemuž se věnuje předkládaný článek. ${ }^{50}$ Postačí uvést, že po státních orgánech by nebylo

46 Sněmovní tisk 557, důvodová zpráva, s. 16.

47 MSD. Legalita stavby zdi na okupovaném palestinském úz̨emi, 2004, odst. 139; MSD. Ožbrojené aktivity na území Konga (Demokratická republika Kongo proti Ugandè), 2005, odst. 146; Současně je však třeba zdůraznit, že MSD výslovně neuvedl, že by sebeobrana směrující proti útoku nestátního aktéra byla nepř́pustná. Pouze judikoval, že pokud by měla být sebeobrana použita proti státu, je nutné dohledat, že je tento původcem ozbrojeného útoku.

48 ILA. Final Report on Aggression and the Use of Force. 2018, s. 14-15. Z posledních let lze zmínit akce Spojených států v Afghánistánu proti al-Káidě, akce Iránu a Turecka v Iráku proti Kurdské straně pracujících, akce Izraele v Libanonu proti Hizballáhu, akce Kolumbie v Ekvádoru proti hnutí FARC, akce na území Sýrie proti tzv. Islámskému státu (k poslednímu prúíladu srov. zejména oficiální nóty adresované předsedovi RB OSN).

49 SCHWEISFURTH, Theodor. Operations to Rescue Nationals in Third States Involving the Use of Force in Relation to the Protection of Human Rights. German Yearbook of International Law, 1980, roč. 23, s. 159-180.

50 Referenčním se v této oblasti stal rozsudek ESLP ze dne 28. 10. 1998, Osman proti Spojenému království. 
možné rozumně očekávat (v dikci odst. 116 citovaného rozsudku ESLP), že hrozbě pro život zabrání právě vojenskou akcí v zahraničí. Mezinárodní právo lidských práv navíc není do sebe uzavřeným systémem, ale odvětvím, které existuje v oceánu jiných pravidel mezinárodního práva, mezi něž patří mj. kogentní zákaz užití síly v mezinárodních vztazích. ${ }^{51}$ Relevantní není ani argumentace humanitární intervencí, ${ }^{52}$ př́padně argumentace její modernější podobou, tzv. odpovědností k ochraně, nebot' ta ,se nestala mezinárodním právem aprobovanou vyjjimkou ze zákazu u乏̌ití síly ani po ozbrojeném zásahu proti Sýrii v dubnu 2018. "53

Nepřesvědčivým se jeví rovněž argument dovolávající se v případě vojenské akce za účelem ochrany vlastních občanů krajní nouze (čl. 26 Návrhu článků) ${ }^{54}$ a případně též tísně (čl. 24 Návrhu článků). ${ }^{55}$ I kdyby bylo akceptováno, že bezprostředně ohroženým podstatným zájmem, jehož existence je podmínkou uplatnění krajní nouze, mưže být rovněž zájem na ochraně života a zdraví vlastních občanů, ${ }^{56}$ resp. pokud by byla považována za splněnou podmínka, předvídaná u tísně, že osoby, k jejichž záchraně by směřovala daná ozbrojená akce, byly svěřeny do péče orgánu státu, dovolání se jednoho či druhého institutu je zapovězeno v čl. 26 Návrhu článkủ, který výslovně uvádí, že okolnosti

51 ESLP využil naznačený externí systematický výklad např. v souvislosti s institutem jurisdikčních imunit státu, srov. rozsudek ESLP ze dne 21. 11. 2001, Al-Adsani proti Spojenému království, odst. 55.

52 Ochrana vlastních občanů je částí nauky považována za tzv. první generaci humanitární intervence - srov. TYAGI, Jogesh. The Concept of Humanitarian Intervention Revisited. Michigan Journal of International Law, 1995, roč. 16, č. 3, s. 885.

53 Konceptu humanitární intervence se v dubnu 2018 po útocích na sklady chemických zbraní v Sýrii dovolávala Velká Británie. Srov. SVAČEK, Ondřej. Kosovo jako laboratoř užití síly v mezinárodním právu. In: KYSELOVSKÁ, Tereza, David SEHNÁLEK a Naděžda ROZEHNALOVÁ (eds.) IN VARIETATE CONCORDIA: soubor védeckéch stati ke poctě prof. Vladimíra Týče. Brno: Masarykova univerzita, 2019, s. 356-361.

54 RABY, Jean. The State of Necessity and the Use of Force to Protect Nationals. Canadian Yearbook of International Law, 1989, roč. 26, s. 253-272; Návrh článků v čl. 25 stanoví následující: Stát se nemůže dovolávat nouze jako důvodu vylučujícího protiprávnost chování, které není v souladu s mezinárodním závazkem tohoto státu, ledaže chování: a) je jediným prostředkem k ochraně podstatného zájmu státu proti vážnému a bezprostředně hrozícímu nebezpečí, b) není závazným způsobem dotčen podstatný zájem státu nebo států, vůči nimž závazek existoval, nebo podstatný zájem mezinárodního společenství jako celku.

55 CRAWFORD, James et al. The Law of International Responsibility. Oxford: OUP, 2010, s. 486; Návrh článků v čl. 24 stanoví následující: Protiprávnost chování státu, jež není v souladu s mezinárodním závazkem tohoto státu, je vyloučena, jestliže původce chování nemá jinou rozumnou možnost, v situaci tísně, pro záchranu života původce nebo životů jiných osob svěřených do jeho péče.

56 Podstatný zájem není pojímán krajně jako zájem, který je nezbytný k holému přežití státu. Teoreticky by se tak mohlo jednat rovněž o situace související se záchranou vlastních občanů. Ibid., s. 496. 
vylučující protiprávnost nemohou být použity $\mathrm{k}$ ospravedlnění porušení kogentních norem, mezi něž patři rovněž (a primárně) zákaz užití síly. ${ }^{57}$

Sporná je rovněž existence svébytné výjimky, vytvořené a ustálené s ohledem na četné př́ipady praxe států zajišt'ujících vojenskou ochranu/záchranu vlastních občanů v zahraničí. ${ }^{58}$ Zastánci tohoto přístupu vycházejí z početné praxe států po roce $1945 .{ }^{59}$ Problémem však zůstává, že tato praxe se (materiálně) týká poměrně úzké skupiny států (zejména Spojených států, Velké Británie, Francie, Belgie a Izraele), v poslední dekádě pak ještě Ruska. Početnější skupina států naopak při různých přiležitostech užití síly za účelem ochrany občanů odmítlo, at’ už se jednalo o verbální reakci na konkrétní incidenty, nebo např. komentáře při projednávání shora citovaného návrhu článku předloženého Dugardem. ${ }^{60}$ Zdá se, že praxe států je roztř̌šštěná, což je ovšem v rozporu s požadavky kladenými na vznik obecného pravidla obyčejového mezinárodního práva. ${ }^{61}$

\section{Závěr}

Co tedy vyplývá z předchozího výkladu? V zásadě jediné: nelze formulovat jednoznačný závěr o tom, že by ozbrojené akce za účelem ochrany vlastních občanů v zahraničí byly v souladu s mezinárodním právem. Bylo řečeno, že se nelze dovolávat obyčejového mezinárodního práva předcházejícího přijetí Charty. Samotná Charta by mohla být využita jako právní základ vojenské akce tohoto typu pouze za předpokladu př́ekonání řady právních překážek, tj. za předpokladu přijetí nikoliv všeobecně sdíleného širšího výkladu akceptujícího jednak personální rozměr ozbrojeného útoku, jednak relevanci nestátního

57 Již z předchozího textu je patrné, že zákaz užití síly je zde pojímán jako exemplární př́ípad kogentní mezinárodněprávní normy. Jestliže tedy dojde $\mathrm{k}$ užití síly na území jiného státu, byt' s bohulibým účelem (typicky u konceptu humanitární intervence, ale stejně tak v př́padě ochrany či záchrany vlastních občanů), lze bez dalšího hovořit o porušení kogentní normy. Současně však není možné přehlédnout, že část nauky zastává názor odlišný, přičemž kogentní povahu přiznává pouze aktu agrese (jakožto nejzávažnějšímu porušení pravidel v oblasti zákazu užití síly) - srov. DE HOOGH, André. Jus Cogens and the Use of Armed Force. In: WELLER, Marc (ed.). The Oxford Handbook of the Use of Force in International Law. Oxford: OUP, 2015, s. 1175; Jako již mnohokrát v předchozím výkladu lze říci, že mezinárodněprávní regulace (a její povaha) je v tomto ohledu nejasná - srov. ILA. Final Report on Aggression and the Use of Force. 2018, s. 4. Autor předkládaného textu se přesto kloní k závěru, že kogentní povahu má pravidlo zakazující užití síly jako celek, tedy nikoliv jen jeho pomyslný vrchol v podobě aktu agrese, což ostatně potvrdil rovněž MSD (v odkazu na práci Komise OSN pro mezinárodní právo) - srov. Nikaragua proti Spojeným státuim, odst. 190.

58 Srov. RONZITTI, Natalino. The Expanding Law of Self-Defence. Journal of Conflict and Security Law, 2006, roč. 11, č. 3, s. 354; Jak uvádí Ronzitti, toto právo jako svébytné, tj. nezávislé na sebeobraně, se ustálilo již v období před rokem 1945 a přežilo rovněž přijetí Charty.

59 DÖRR, op. cit., s. 1296-1297. Dle Dörra se obyčejové pravidlo vytvořilo až v souvislosti s praxí států po roce 1945 .

60 Jedná se o Argentinu, Burkinu Faso, Etiopii, Ghanu, Čínu, Kolumbii, Kubu, Irán, Irák, Jordánsko, Libyi, Mexiko, Polsko, Slovinsko a Venezuelu.

61 Obdobně RUYS, op. cit., s. 241; FORTEAU, op. cit., s. 961; Srov. rovněž Independent International FactFinding Mission on Conflict in Georgia. Report, roč. 2, s. 286-287. 
aktéra coby původce ozbrojeného útoku. Přesvědčivým se jeví odmítnutí ostatních linií obhajujících vojenskou ochranu občanů v zahraničí, včetně tvrzeně vytvořené svébytné obyčejové výjimky. Shoda panuje snad jen v tom, že za souladné s mezinárodním právem - při využití tísně či krajní nouze jako okolností vylučujících protiprávnost - jsou považovány nevojenské evakuační operace.

Současně však nelze přehlížet, že se v praxi případy vojenských záchranných akcí občanů čelících v zahraničí bezprostřednímu ohrožení objevují. Autor předkládaného textu proto formuluje následující závěr: vojenská akce za účelem ochrany občanů bezprostředně ohrožených v zahraničí je nelegální, nebot’ odporuje zákazu užití síly, nicméně při splnění určitých podmínek zůstává legitimní. ${ }^{62}$

Tyto podmínky byly formulovány ve shora citovaném Dugardově návrhu, jenž navazoval na předchozí práci H. Waldocka. ${ }^{63}$ Musí se jednat o bleskovou akci, chirurgický řez, ${ }^{64} \mathrm{z}$ něhož bude dostatečně patrné, že jediným a výlučným cílem intervenujícího státu je záchrana bezprostředně ohrožených občanů. Zdůrazněna je rovněž subsidiarita - k vojenské akci tohoto typu tudíž může být přistoupeno pouze tehdy, kdy situace nemůže být vyřešena $\mathrm{v}$ koordinaci s teritoriálním státem (jednalo by se např. o zhroucené státy). Po skončení této akce musí dojít k okamžitému stažení ozbrojených sil. Samozřejmým předpokladem vojenského zásahu je existence reálného státoobčanského pouta mezi zachraňovanými jednotlivci a intervenujícím státem. ${ }^{65}$ Zcela zjevně nepostačí vazba založená na pouhé národnosti. Rámec mezinárodněprávní úpravy zde tvoří čl. 1 Haagské úmluvy o některých otázkách střetů zákonů o státním občanství z roku 1930, ${ }^{66}$ reflektující obyčejové mezinárodní právo, z níž vyplývá, že udělování státního občanství sice představuje suverénní prerogativu každého státu, nicméně současně musí být zajištěn soulad s omezeními plynoucími z mezinárodního práva. Mezinárodněprávní relevanci by proto nemělo občanství, které by bylo uděleno v rozporu s vưlí dotyčného jednotlivce, dále občanství udělované osobám žijícím na území a majícím občanství jiného státu, nebot’ by se jednalo o zásah do suverenity tohoto státu, ${ }^{67}$ resp. občanství, které

62 Argument legitimity je sice v mezinárodním právu bežpředmětný, má však značnou relevanci v oblasti zahraniční politiky. Srov. FAIX, Martin a Ondřej SVAČEK. Use of Force in International Law: Need for Methodological Debate. Czech Yearbook of Public and Private International Law, 2018, roč. 8, s. 108-109.

63 Waldock formuloval následující podmínky: (a) existence skutečného a bezprostředního nebezpečí zranění (injury) vlastních občanů; (b) nečinnost či neschopnost teritoriálního státu zajistit ochranu; (c) intervenující stát jedná s výlučným cílem zajistit ochranu vlastním občanům. Srov. WALDOCK, op. cit., s. 467.

64 BÍLKOVÁ, op. cit., s. 11.

65 Není prritom podstatné, že vedle vlastních občanů jsou v konkrétním případě zachráněni rovněž občané třetích států. Srov. DINSTEIN, op. cit., s. 259.

66 Haagská úmluva v čl. 1 stanoví následující: Je věcí každého státu určit podle svého vlastního práva, kdo jsou jeho občané. Toto právo jiné státy uznají, pokud je tato úprava v souladu s mezinárodními úmluvami, mezinárodním obyčejem a zásadami práva všeobecně uznávanými s ohledem na občanství.

67 Tento závěr lze odvodit z posudku SDMS ve věci Dekretů o občanství vyblášených v Tunisku a Maroku, 1923. 
by nesplňovalo podmínku tzv. skutečného pouta (genuine link). ${ }^{68} \mathrm{~S}$ těmito požadavky je jednoznačně v rozporu praxe tzv. pasportizace, tj. hromadného udělování státního občanství a následného vystavení pasů občanům třetích států, v nedávné době realizovaná Ruskem v Jižní Osetii, Abcházii a na Krymu.

Splnění těchto podmínek neučiní z vojenské akce na území jiného státu akci souladnou s mezinárodním právem, nicméně poskytne jí beneficium legitimity, jež by působilo coby polehčující okolnost a poskytovalo by argument, že se v takovém případě nejednalo o zjevný akt agrese. Uvedené zhodnocení je patrně maximem, kterého může intervenující stát s ohledem na současný stav mezinárodněprávní rámce v oblasti zákazu užití síly dosáhnout. S tímto předporozuměním by mělo být přistupováno rovněž $\mathrm{k}$ navrhované novelizaci čl. 43 Ústavy.

68 Srov. MSD. Nottebohm (Lichtenštejnsko proti Guatemale). 1955. 